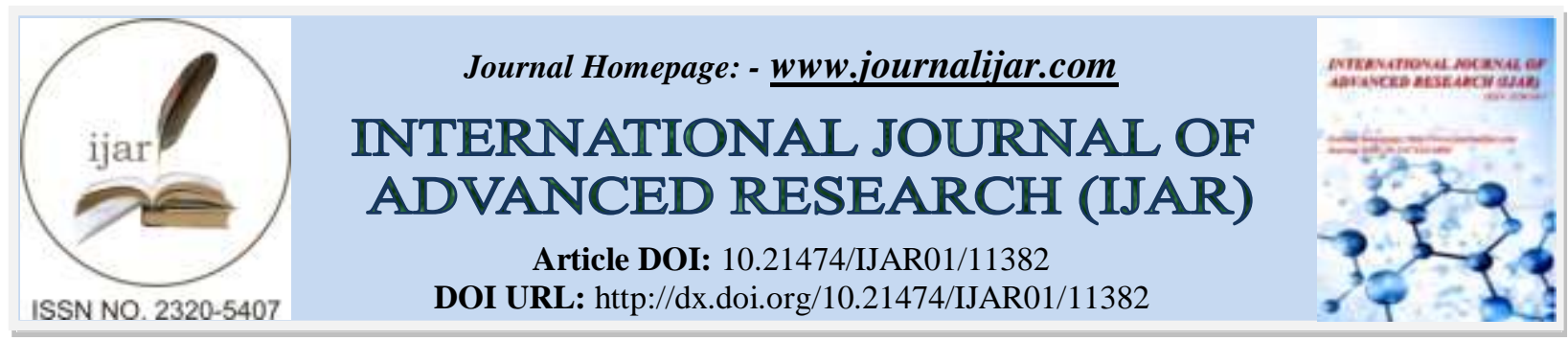

RESEARCH ARTICLE

\title{
POST-GENITAL MUTILATION CLITORAL CYST COMPLICATED BY LOWER URINARY TRACT
} SYMPTOMS

\author{
Modou Ndiaye, Ibrahima Dara Diame, Cheikh Dieng, Ousmane sow, Ibrahima Diallo, Ameth Mbodji, \\ Ndiaga Seck Ndour, Tiennou Hafing, Yaya Sow and Boubacar Fall
}

\section{Manuscript Info}

Manuscript History

Received: 20 May 2020

Final Accepted: 24 June 2020

Published: July 2020

Key words:-

Cyst, Clitoris, Genital Mutulation,

Clitoridoplasty

\section{Abstract}

Objective: to describe the epidemiological, clinical and therapeutic aspect of the clitoral cysts complicated by lower urinary tract symptoms managed in a urological setting.

Patients and Method: This is a retrospective, descriptive, and singlecenter study of patient records received for low urinary tract symptoms due to a post excisional clitoral cyst over a two-year period. The studied parameters were: incidence, age, circumstances of discovery, physical examination and treatment.

Results: Twelve patients were included with an annual incidence of 4. The mean age was $20.5 \pm 11.3$ years. The examination revealed lower urinary tract symptoms, a clitoral cyst at the level of the clitoridectomy area. Cyst excision associated with clitoridoplasty was performed in all patients with a simple operative follow-up.

Conclusion: The management consisted of a surgical resection associated or not with a clitoridoplasty.

Copy Right, IJAR, 2020,. All rights reserved.

\section{Introduction:-}

Female genital mutilation (FGM) refers to all procedures performed on the female external genitalia (EMB) including their partial or total removal for a non-medical reason (WHO definition) [1]. These mutilations still affect between 130 and 150 million young girls around the world today, and it is estimated that two million children are at risk of FGM each year [2]. In France, MFG are practiced by French of African ethnic who come mainly from three countries: Senegal, Mali and Mauritania [3]. In Senegal, MFG type 1 and 2 are more commonly practiced [4; 5]. While immediate complications are dominated by hemorrhage, infection and urethral lesions but the late complications such as vulvar masses especially clitoral cysts are poorly documented [5]. These clitoral cysts, although rare, can cause obstruction of the urethral meatus and lead to lower urinary tract symptoms. The objective of our study was to describe the clinical and therapeutic aspects of her clitoral cysts complicated by lower urinary tract symptoms managed in a urological setting.

\section{Patients and Method:-}

This is a retrospective, descriptive and mono-center study, collecting the files of patients received for the taking of lower urinary tract symptoms due to a post-excisional clitoral cyst during the period January 2015 to December 2017 in the department of urology-andrology of the regional hospital of Ourossogui (North of Senegal). All patients with lower urinary tract symptoms due to a post-excisional clitoral cyst were included. All patients with an incomplete file and those who had no surgical procedures were not included. The parameters studied were: 
incidence, age, circumstances of discovery, lesional aspects, treatment performed and results. The procedure consisted of a one-piece excision of the cyst followed by clitoridoplasty without touching the urethra. The data collection, the preparation of the figures, the calculation of the means and standard deviation were done with Microsoft-Excel 2013 software.

\section{Results:-}

Twelve patients were included over a period of three years, either an annual incidence of 4 per year. The mean age of the patients was $20.5 \pm 11.3$ years and the most represented age group was between 10 and 20 years (Figure 1). All the patients were seen for consultation with lower urinary tract symptoms made up of pushing effort type dysuria, associated with a sensation of a mass in the urethral meatus. This mass sometimes needed to be pushed back to allow urine evacuation in four patients. Four patients were married and their interrogation also noted a sexual disorder with a decrease in libido. This symptomatology were evolving for at least a year. The physical examination revealed a painless rounded mass, 2 to 12 centimeter in diameter, located in the area of the clitoridectomy, pink or blackish in color, of a renitant consistency, pedicled and mobile in relation to the two planes. The skin opposite was healthy (Figure 2). All patients was performed a cyst resection associated with clitoridoplasty (Figure 3, 4).

It is no intraoperative complications nor postoperative. Ablation of the urinary catheter did the day 1 postoperatively and the lower urinary tract symptoms disappeared in all patients. The final aesthetic appearance was satisfactory in all patients and the patients married had an improvement in their libido.

\section{Discussion:-}

In Senegal, the overall rate of genital mutilation is estimated at $20 \%$ of the female population, either a rate of 750000 women concerned [6]. The clitoral cyst is a rare complication of MFG, which progresses slowly and treatment is sometimes late. It occurs within 10 to 20 years [7]. The annual incidence in our series for post-excision clitoral cysts revealed by lower urinary tract symptoms was four despite the rarity of this complication confirming that this traditional rite is still relevant in our country. Indeed, despite the many awareness campaigns and the criminalization of this practice, FGM continues to be illegally practiced in our country. The reasons given for FGM are:

Search of "beauty and cleanliness" external genitalia are considered "ugly and unhygienic", These acts were a mean to become a "real woman"; male approval and protection: excision is a mean of integration into the community. Young girls who were not cut cannot marry; religion and morals: excision protect the women virginity and avoid sexual deviations [5].

The mean age of our patients was $20.5 \pm 11.3$ years and the most represented age slice was between 10 and 20 . This age was close to the age at 25.4 years, found by Diouf \& al. [4] in their series. In our series, two patients were less than 10 years old, which confirms that this traditional rite is preferably practiced in childhood. For practitioners, this initiation prepare the girl to her life futur woman's and give it than its place in the community. All the patients were seen for consultation with lower urinary trac symptoms made up of pushing effort type dysuria associated with a feeling of mass in the urethral meatus. For the patients who were married despite their low libido type sexual disorder, they did not come for consultation for this reason. This consultation delay can be explained by the fact that in our regions sexuality is considered a taboo subject. This dysuria, that was growing more, took the view ahead. Type 2 FGM has been objectified in all our patients, which confirms the fact that in Senegal, type 1 and 2 FGM are more frequently performed $[4 ; 5]$. The treatment consisted of a resection associated with a clitoridoplasty. What seemed us to be more logical given the young age of the patients in our series. This clitoridoplasty achieves a significant improvement in aesthetic appearance and sexual satisfaction [8; 9] unlike Diouf et al. [4] who did not consider necessary to perform an associated clitoridoplasty in their series.

\section{Conclusion:-}

The clitoral cyst is a rare complication and unfamiliar MFG may be responsible for lower urinary tract symptoms. The management in this case consists of a surgical excision associated or not with a clitoridoplasty. It gives satisfactory functional and aesthetic results.

Figure 1: Distribution of patients by age slice

Figure 2: Clinical appearance of the clitoral cyst 
Figure 3: Image of monobloc excision of the clitoral cyst

Figures 4: Immediate postoperative results after clitoridoplasty

\section{Acknowledgment:-}

We thank all the hospital staff in particular the Ourossogui's operating room staff, surgery and maternity.

\section{Declaration of conflicts of interest:}

There are no conflicts of interest.

\section{Authors' contributions:}

Modou Ndiaye *, Ibrahima Dara Diame, Cheikh Dieng, Ameth Mbodji, Tiennou Hafing, Ndiaga Seck Ndour, Ousmane Sow: all participated in the data collection.

Ibrahima Dara Diame, Yaya Sow, Boubacar Fall: all read, corrected and approved the final document Modou Ndiaye, Ibrahima Dara Diame : have a major role in the design and development of the document.

\section{Source of funding:}

No.

\section{Approval of the ethics committee:}

The ethics committee of the regional hospital of Ourossogui approved the document.

\section{Patient consent:}

The informed consent was sought and obtained orally.

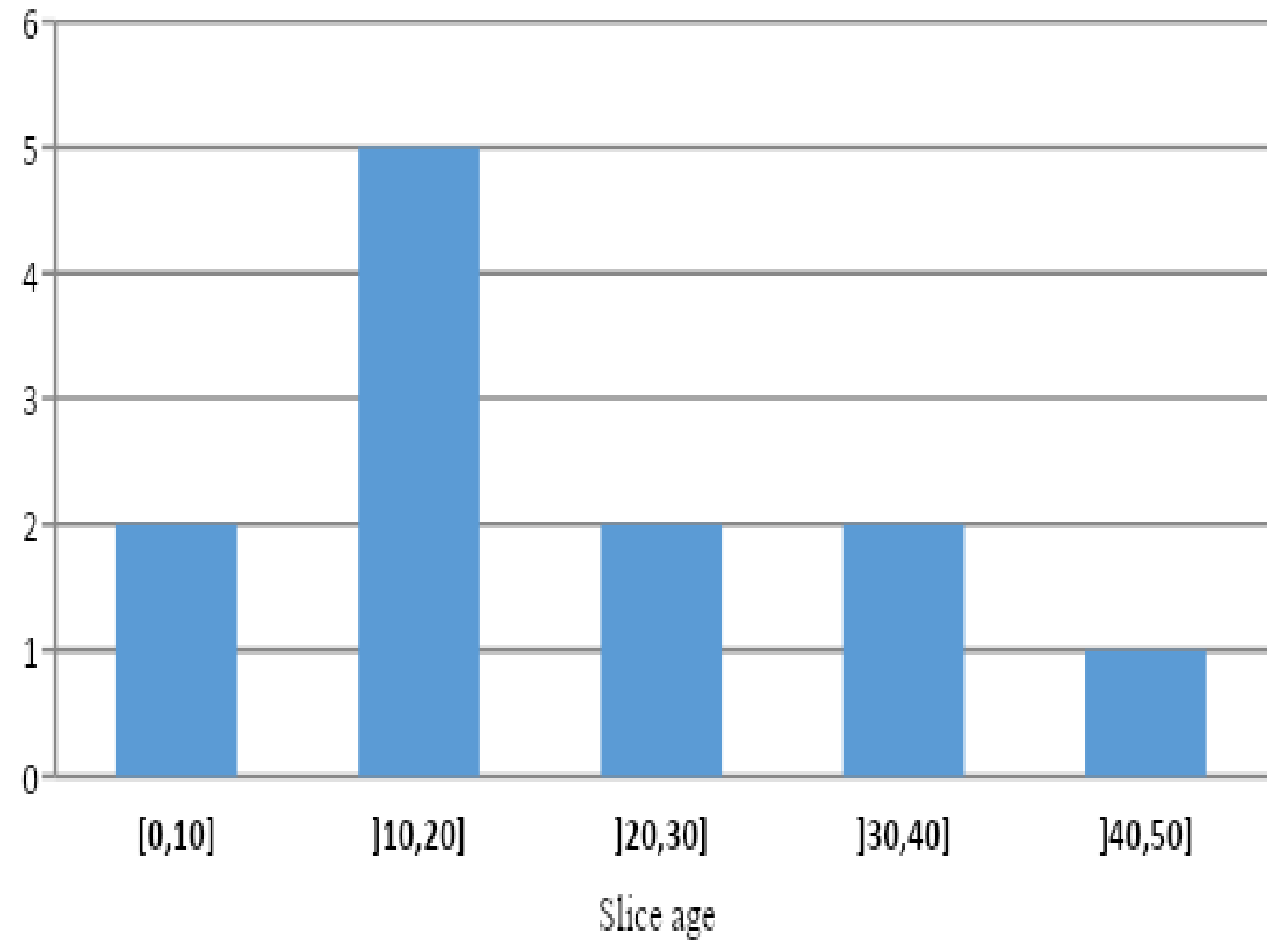

Figure 1:- Distribution of patients by slice age. 


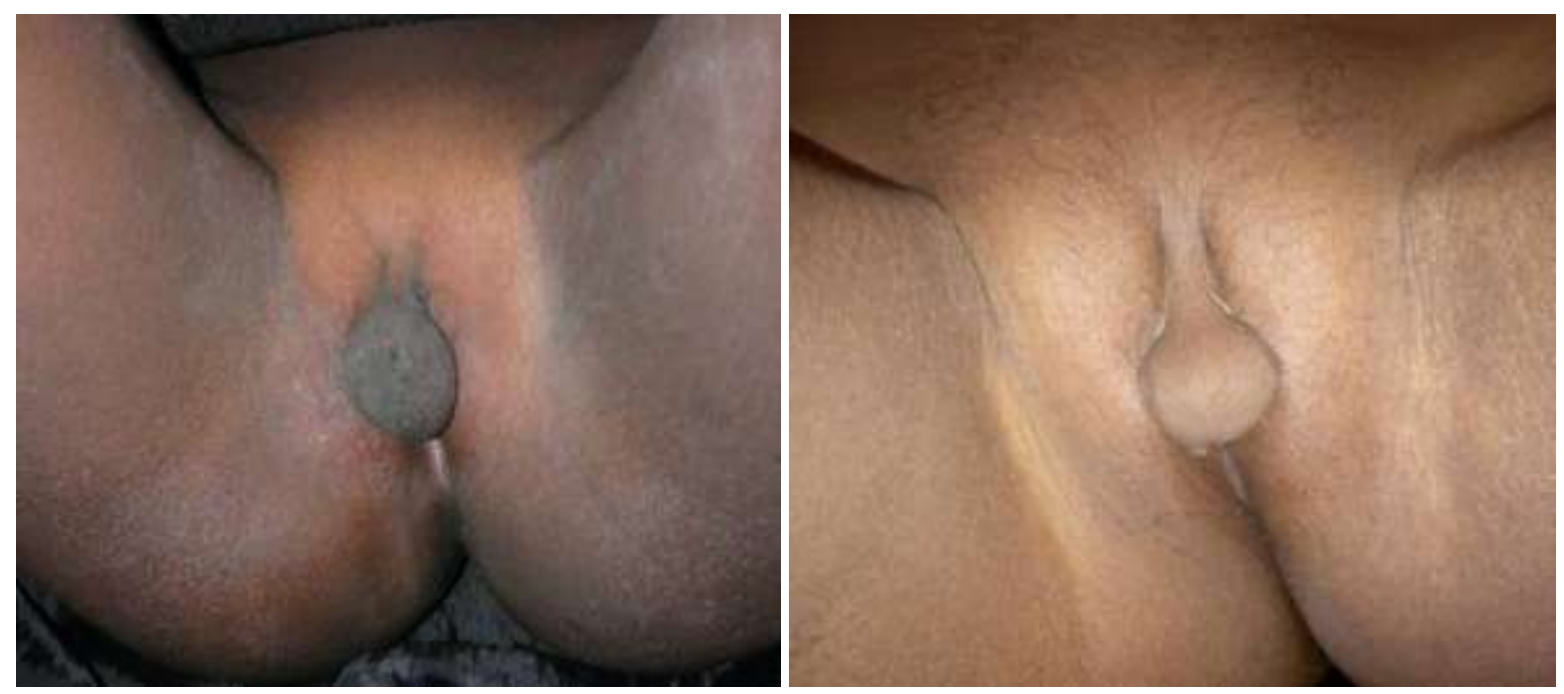

Figure 2:- clinical appearance of the clitoral cyst.

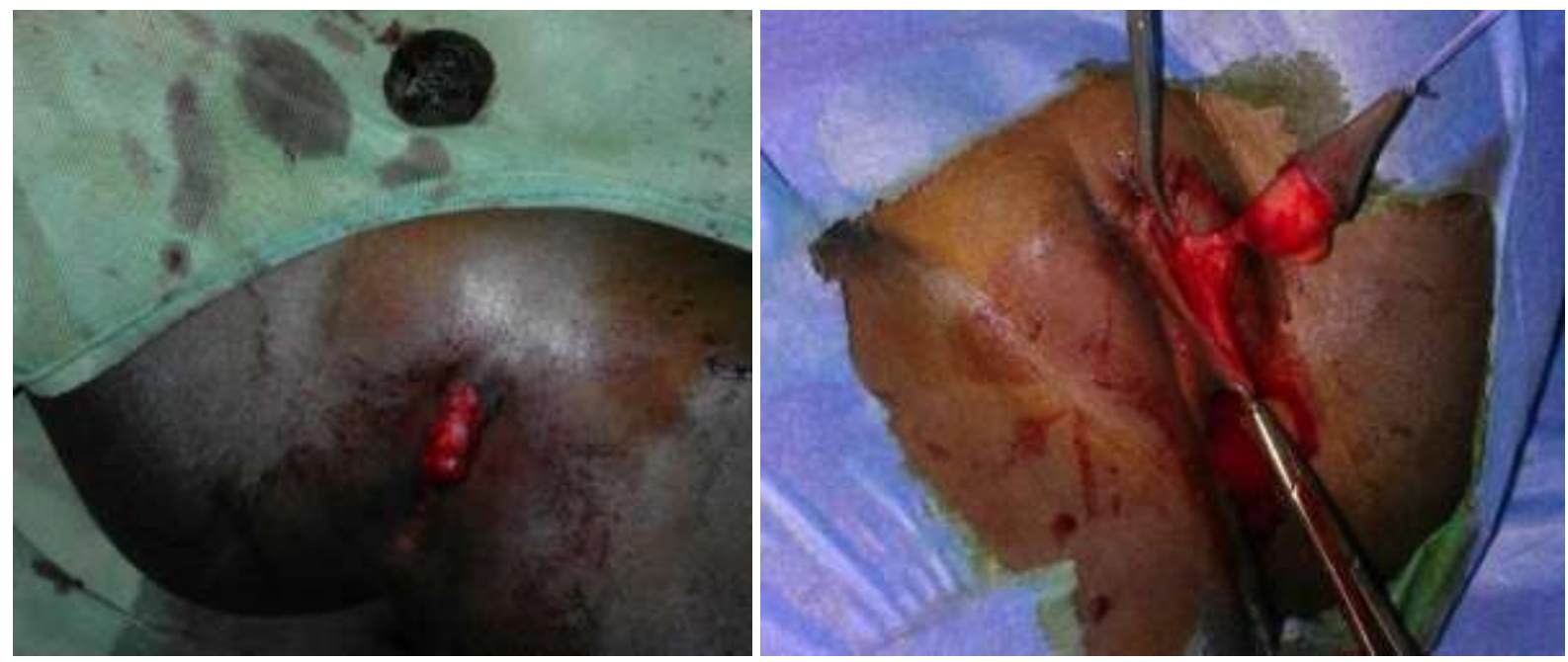

Figure 3:- Image of monobloc excision of the clitoral cyst.

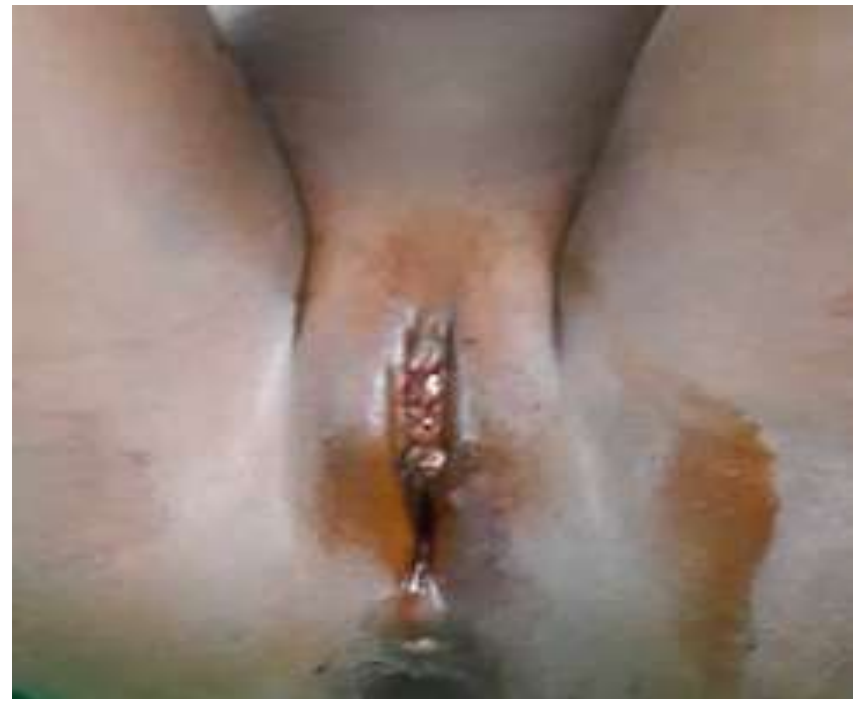

Figures 4:- immediate postoperative results after clitoridoplasty. 


\section{References:-}

1. Collinet P, Sabban F, Lucot J-P, Boukerrou M, Stien L, Leroy J-L. Prise en charge des mutilations génitales féminines de type III. J Gynécologie Obstétrique Biol Reprod 2004; 33:720-724.

2. Toubia N, Izett S. Female genital mutilation: an overview. Geneva: World Health Organization; 1998. 73 p. http://apps.who.int/iris/handle/10665/42042

3. Rey-Salmon C, Vazquez P, Do Quang LD. Les mutilations sexuelles féminines. Arch Pediatr 2005;12:347350.

4. Diouf AA, Mbaye M, Gueye M, Coly AN, Moreira P, Moreau JC, et al. Traitement chirurgical des kystes clitoridiens compliquant des mutilations génitales féminines. J Gynécologie Obstétrique Biol Reprod 2014;43:328-331.

5. Moreira PM, Moreira IV, Faye EHO, Cisse L, Mendes V, Diadhiou F. 3 cases of vulvar epidermal cysts after female genital mutilation]. Gynecol Obstet Fertil 2002;30:958-960.

6. ENDA. In Anual report; 1993. http://endacremed.org/bpd/opac_cssindex.php?lvl=notice_display\&id=4484

7. Mseddi M, Bouassida S, Turki H. La mutilation génitale féminine. Sexologies 2006;15:262-265.

8. Foldes P, Droupy S, Cuzin B. Chirurgie cosmétique de l'appareil génital féminin. Prog Urol 2013;23:601-611.

9. Ouedraogo CMR, Madzou S, Toure B, Ouédraogo A, Ouedraogo S, Lankoande J. Pratique de la chirurgie plastique reconstructrice du clitoris après mutilations génitales au Burkina Faso. À propos de 94 cas. Ann Chir Plast Esthét 2013;58:208-215. 